(2) The "lateral carpal" unites both with the distal carpal and with the "pteroid" by very free, well-defined articulations.

(3) In American specimens, the "Iateral carpal" stands nearly at right angles to the wrist, and the "pteroid" is much bent near its articular end.

(4) In no Pterodactyle known is there any remnant of a digit outside the wing finger, where the membrane might be expected to retain it.

(5) This view would make the wing finger of the fifth digit, the same to which the membrane is attached in the hind foot.

Perhaps the strongest objection against this interpretation is the number of phalanges in the respective digits of the hand. These, however are not constant in the known Pterodactyles, and they vary much in other reptiles which have the digits highly specialised. This subject will be more fully discussed by the writer elsewhere.

According to the above interpretation, there are five digits in the hand of Pterodactyles, although not the five often given in restorations. The first digit, the elements of which have been considered, undoubtedly supported a membrane in front of the arm. The second, third, and fourth are small, and armed with claws. The large wing finger is the fifth, corresponding to the little finger of the human hand.

The metacarpal bones are much elongated in the Pterodactyles with short tails, and quite short in those, like the present specimen, that have the tail long. The metacarpal of the wing finger is always large and robust, while those of the claw bearing digits are usually quite slender. In Pteranodon, the second metacarpal is a slender thread of bone throughout most of the length, while the third and fourth are attenuated splint bones, incomplete above.

The phalanges of the three middle digits are quite short, and the terminal ones supported sharp claws. The wing finger has four greatly elongated phalanges, the last being a styloid bone without a claw. This digit is well shown in the right wing represented in Fig. $\mathbf{I}$, and also in the restoration, given below in Fig. 3 .

In the restoration here attempted, the writer has endeavoured to reproduce (I) the parts actually present or clearly indicated in the specimen described, and (2) those which the former seemed to require to complete the outward form in life. The membrane at the base of the tail may have been somewhat less in extent, and the fold of the skin above the fore-arm either more or less developed than here represented, but the facts now known render the outlines here given more than probable. The hands are represented with the palms forward.

The present species appears to be most nearly related to Rhamphorhynchus Gemmingi, von Meyer, from the same geological horizon, and near the same locality. That it is quite distinct, however, is shown, aside from the difference in size, by the complete ankylosis of the scapula and coracoid, and by the fifth digit of the hind foot being well developed, and having three phalanges. In the name Rhamphorhynchus phyllurus, here proposed for the species, the latter designation refers to the leaf-shaped caudal appendage, which appears to be one of its most characteristic features.

For the long delay in the description of this important European specimen, the writer can only plead le einbarras des richesses nearer home.

Yale College, New Haven, March I4

\section{THE INSTITUTION OF NAVAL ARCHITECTS}

THE annual meetings of the Institution were held this year on the 29th, 3oth, and 3 ist of March. The programme included no less than nineteen papers, not one of which could in any sense be called a stop-gap. It seems a pity that this Institution should hold but one meeting in the year. The time available for reading papers on the three days amounts in all to but twenty hours, which Jeaves about one hour for the reading and discussion of each paper. It is no exaggeration to say that many of the subjects considered at the recent meetings required a whole day for their adequate discussion, and would have received this allowance of time at any other institution. The true interests of the naval architects are sure to suffer in the long run, if the present policy of cramming so many papers into the short space of time available at the meeting is adhered to. The first paper read, and the only one which dealt directly with ships of war, was by Mr. Samuda. It was an attempt to controvert the arguments made use of by Sir Wm. Armstrong in his recent address to the Institution of Civil Engineers. The address in question has been generally construed into a defence of unarmoured as against iron-clad ships. Sir William Armstrong states that for the cost of one ironclad we could have three unarmoured ships, each carrying the armament of the iron-clad, and that in a match between the iron-clad and her three supposed antagonists they would probably get the better of it. Mr. Samuda, however, points out, that in fleet fighting, which he supposes will in the future, as in the past, be the principal form of naval combat, this advantage of the many unarmoured ships against the few iron-clads would disappear.

Mr. Samuda further argues that the recent improvements in the construction of the hulls and armour of war ships, due to the introduction of mild steel instead of iron, has at least neutralised the extraordinary improvements made in the guns in the last few years. He also warned his hearers against the disastrous consequences which may be brought about through false economy in naval construction.

The opinion of the meeting as evoked in the discussion was certainly in favour of Mr. Samuda's arguments. Several distinguished naval officers, including Admirals Hornby and De Horsey, and Captain Noel, spoke emphatically of unarmoured war ships as being utterly useless for fighting purposes if opposed by ironclads. They dwelt on the great value of even a moderate amount of armour, in keeping out projectiles which struck obliquely, and in actual combat but few shots would be likely to strike at right angles. Mr. Burnaby also lent the weight of his great authority to the same view of the question. Upon the whole Mr. Samuda may claim to have considerably modified the effect which was pretty generally produced by Sir William Armstrong's address.

Mr. Dunn, Assistant-Constructor at the Admiralty, read an interesting paper on Modern Merchant Ships. This communication dealt incidentally with the capacity of merchant ships for being converted into cruisers for the protection of other merchant vessels in time of war. This is an important subject, when we remember how miserably inadequate the royal navy is for this purpose. The actual money value of the merchant navy of this country falls little, if at all short, of two hundred millions sterling. If to this sum, we add the value of the freight carried, it will be easy to understand how vulnerable as a nation we are at sea. Mr. Dunn has for some time past been employed by the Admiralty in surveying those vessels, which are intended, should the occasion ever arise, to supplement the regular navy in defending the mercantile marine. The important qualities which a merchant steamer must possess in order to be capable of being converted into a man-of-war are speed, structural strength, considerable relative beam, and powerful steering gear. In all these points it is satisfactory to learn that much progress has been made during the last few years. Taking first the question of speed. Between the years 1875 and 1882 , the number of steamers capable of steaming 13 knots and upwards continuously at sea has 
increased from twenty-five to sixty-five. In I 875 there were ten vessels capable of steaming over I 4 knots, now there are thirty-five, while the highest speeds have been increased from 15 to 17 knots. At the same time the power of these vessels of keeping the seas has been greatly increased through the improvements which have been effected in the economy of the marine engine. There are many steamers which can carry coal enough to steam round the world at a io knot speed.

The structural strength of merchant vessels has undergone a remarkable improvement during the last few years, thanks to the increased attention which has been paid to their longitudinal strength, and also to the introduction of steel as a material of construction and of cellular as double bottoms. Doubts have been frequently expressed as to the capability of merchant steamers for carrying guns. A direct experiment was made on this point by the Admiralty in 1878 , during the height of the Russian scare, by the purchase by the Admiralty of the Hecla from Messrs. Harland and Woolf of Belfast. She was armed with five 64-pounders and one 40-pounder, mounted on truck carriages, and has been in commission ever since, and most favourably reported on. As another example we may mention the case of an Irish cattle-boat which was purchased by the Chilians and armed with an I I-ton gun, and which was employed in the bombardment of the Peruvian ports.

Another most important point in considering the question of the structural strength of these steamers is the question of subdivision by water-tight bulkheads. There has been a strange apathy on this subject till very recently in the mercantile marine. Lloyd's rules insisted on the introduction of four bulkheads, viz. one at each end of the ship, and one at each end of the machinery space. The compartments into which a ship was thus subdivided were in general so large that if one of them filled the vessel went down. In many long passenger steamers where more numerous bulkheads were introduced, their useful effect was done away with by the doors through them not being water-tight; or occasionally by their heads being below the water-level. It is however some satisfaction to know that all the passenger vessels built during the last three or four years for the principal lines are properly subdivided.

It is a matter for regret that Mr. Dunn's official position prevented him from enlightening his audience as to the exact degree of useful help which we may look for from this auxiliary navy in case of actual need. We are also left without any information as the organisation, if any, which exists for rapidly equipping and manning these vessels whenever their services may be called for. Considering the scare which was produced in this country in 1878 , by the attempt made by the Russians to convert a few American merchant steamers of very moderate speed into cruisers of the Alabama type, it seems only reasonable to hope that, by utilising the immense resources of our merchant marine, we may find the means of avoiding such panics in the future.

There were some interesting papers read on the subject of marine engines and boilers. Mr. Kirk, of the firm of Messrs. J. R. Napier and Sons, of Glasgow, read an interesting paper on the triple expansive or compound engines which he has recently fitted to the S.S. Aberdeen; and Mr. Parker, Chief Engineer Surveyor to Lloya's Register, followed with a general Faper on the subject of triple and double compound engines. Thoughtiul students of the steam-engine have for some time recognised the fact that one of the principal sources of waste in engines which use steam expansively, is the variation in temperature of the cylinder, due to the difference between the temperature of the steam at the pressures at which it enters and leaves the cylinder. The greater the difference in these pressures, i.e., the greater the range of expansion, the greater also is the difference between the initial and final temperatures of the steam. The consequence is, that the incoming steam finds the cylinder chilled ; a portion of the steam as it enters is condensed, causing a loss of pressure and of useful work. As the steam expands and becomes colder than the surrounding walls of the cylinder, a portion of the condensed steam is re-evaporated towards the end of the stroke, and during the exhaust when it can do no useful work. Thus the cylinder at the commencement of the stroke acts as a condenser, and during the end of the stroke and the exhaust as a boiler. It was to obviate the waste due to the above causes that the compound engine was introduced. In this latter class the steam, instead of being expanded throughout in one cylinder, was allowed to expand partially in a high pressure, and subsequently in a low pressure cylinder. Thus the difference in temperature for each cylinder was balved, and the waste due to condensation proportionately diminished. By degrees, however, the pressures made use of in marine boilers were increased, and consequentiy the range of temperatures even in compound engines became as great as in the old simple expansive engine using lower pressures. To get over this difficulty Mr. Kirk made use of the triple expansive engine, which is really a compound engine again compounded, the steam being expanded successively in three cylinders. In this way the range of temperature is divided into three parts. In the case of the $A b_{\mathrm{c}} \mathrm{rdeen}$ the boiler pressure was I $25 \mathrm{lbs}$. per square inch, and the diameters of the cylinders were respectively 80 in., 45 in., and 70 in., by $4 \mathrm{ft}$. 6 in. in stroke. During a four hours' trial with Penrikyber Welsh coal, the consumption was found to be only I.25 lbs. per indicated horse power per hour, from which very satisfactory result we should be led to expect a sea consumption of from $I^{\prime} 5$ to $I \cdot 6 \mathrm{lbs}$.

Mr. Milton, of Lloyd's Register, read a paper on the influence of Lloyd's Rules on marine boiler construction. This paper was called forth by Mr. Marshall's statement at the Mechanical Engineers' meeting at Newcastle, that "the ordinary marine boiler, encumbered as it is by the rcgulations of the Board of Trade and of Lloyd's Committee, do:s not admit of much reduction in the weight of material or of water carred when working." Mr. Milton has endeavoured with considerable success to prove that the above remark, so far at least as it applies to Lloyd's, is far from expressing the truth. He explains very clearly the principles on which Lloyd's base their rules. The most important part of his paper is that in which he attempts to show that Fairbairn's rules, as to the strength of cylinders pressed from without, are very erroneous when applied to flues having the dimensions of those of marine boilers. Mr. Milton does not speak hopefully of the use of locomotive boilers for marine purposes. We trust, for the sake of the country, that his experience may not be confirmed by the Admiralty experiments with the Polyphemus, which vessel is, as is well known, entirely fitted with boilers of the locomotive type.

Mr. W. H. White, Chief Constructor at the Admiralty, read a most important paper on the Revision of the Tonnage Laws, which we intend to make the subject of a separate notice. It was followed by two communications from Mr. Martell, Chief Surveyor at Lloyd's, and Mr. W. Rundell, Secretary of the Liverpool Underworiter Register, on the subject of Load Line, a topic which for many years past has been the subject of much heated argument. Mr. Martell discusses freely the latest proposals of the Board of Trade, and considers in detail the practical considerations which should determine the load line for vessels of various clasess. He is of opinion that the day has passed for the acceptance by shipowners and builders of any scheme for loading which does not take cognisance of the form and other elements of a vessel, in addition to the length, depth, or size. He winds up his paper with the following sentence, which may well be commended to the shipowning community. "I cannot 
help feeling that shipowners in their own interests would adopt a wise course by supplying correct data, and otherwise considering the question of framing rules, based on sound principles, which would take cognisance of all the surrounding elements affecting this complex q'xestion, and thereby enable rules and tables to be framed which would be accepted as a fair compromise, and equitable and sound reference fo: the future guidance of all interested in this important subject, and the result of which would, without doubt, tend to diminish the loss of much valuable property and the sacrifice of many human lives."

Messrs. Read and Jenkins, of Lloyd's Register, contribute a valuable investigation into the transverse strains of iron ships. This subject uas, we believe, first investigated vigorously by $\mathrm{Mr}$. W. John, who read a paper on the same subject in 1877 , before the Institution of Naval Architects. The method of treatment pursued by Messrs. Read and Jenkins is too technical to reproduce at length in these pages. After investigating the strains of foir steam-vessels, supposed to be docked when loadef with cargo of the density of coal, up to the height of the lowest tier of beams, they conclude with the important observation that the results demonstrate, in an unmistakable manner, how necessary it is to provide additional transverse strengthening in the engine and boiler space in steam-vessels, where the localised weights of the engines and boilers, and the want of support from the deck above, due to the small number of beams, increase the strain of the middle line and bilge.

The most interesting of the remaining papers were two by Mr. T. Harvard Biles, naval architect to Messrs. J. and G. Thompson, of Glasgow, on Progressive Speed Trials, and on the Curves of Stability of Certain Mail Steamers. The former paper was of great practical value to naval architects, as it affords to all the means of carrying out progressive trials with ease and rapidity. Mr. Biles abandons the measured mile trial, because of the inseparable inaccuracies which attende 1 it. These were due to the varying and unknown rate at which the tide flows, and to the impossibility of knowing whether the ship, when she comes on the mile, is running at her proper speed, or is accelerating her own motion. Mr. Biles throws out from the bow of the ship a floating object which is observed as it passes a a set of transverse sights fixed on the ship about one hundred feet from the bow, and again when it passes another pair of sights fixed at a given distance from the first pair. The time occupied in the transit is recorded by an electric apparatus, which also at the same time records seconds automatically, and also the number of revolutions of the engine. The floating object moves with the tide, and therefore the speed of flow of the latter need not be taken into account. By means of this apparatus, builders can measure the true speed at which their vessels are travelling when steaming right ahead, and consequently can derive all the information to be obtained from progressive trials, without resorting to the oldfashioned, tedious system of runs on the measured mile.

We regret that want of space prevents us from noticing the remaining papers read at these meetings, not one of which was deficient in interest.

\section{NEW AND VERY RARE FISH FROM THE MEDITERRANEAN}

$\mathrm{N}^{\mathrm{N}}$ a long ichthyological excursion which I undertook by order of the Minister of Public Instruction in November and December last, during which I explored our Adriatic coast from Ancona to Lecce, the Ionian shores from Taranto to Reggio (Calabria), and visited the two seas of Sicily, collecting principally at Messina, Catania, and Palermo; I collected above 2000 specimens of fish, amongst which were many rare species, and several quite new to the ichthyofauna of the Mediterranean. Amongst the latter I may mention a large and perfect specimen of Molva vulgaris, fou id in the market of Catania; this is a North Atlantic species, and has not yet been recorded from the Mediterranean; there has been, it is true, for many years a dried skin specimen in the Genoa University Museum, which was figured in 1864 by Canestrini as Haloporphyrus lepidion, and six years afterwards corrected by the same author as Lota vulgaris. About a year ago Dr. Vinciguerra and myself determined it correctly, but as no data as to its capture had been preserved, we were in considerable doubt as to its being a Mediterranean specimen. At Palermo, where I went after leaving Catania, I found a third Italian spezimen of this species. At Messina I collected two specimens of Scorpona ustulati, Lowe, aud a fine specimen of Umbrina ronchus, Val,, both new, to our fauna. I believe that most of the Madeira species will eventually be found in the Mediterranean, especially off the Sicilian coasts. Messina is a splendid locality for deep-sea or pelagic forms; it appears that during stormy weather, especially from the south-east, many abyssal species are in some way thrown up, and may be found in hundreds floating in the Messina harbour, which stretches like a net or trap across the Straits; such are Chauliodus, Stomias, Argyropelecus, Microstoma, Coccia, Maurolicus, Gonostoma, and some ten or twelve species of Scopelus. While there last November I secured a fine Malacocephalus lavis, and a singular fish of a deep black colour, with small eyes and a naked skin, and a most abyssal physiognomy, which is quite new to me, and which I have not yet been able to determine; it may be allied to Malacosteus.

I shall close these notes by mentioning the capture of a very strange fish (belongins to the singular Notacanthi), which may well be called the rarest of fishes. It is a small specimen evidently closely allied to Notacanthus Rissocmus, De Filip, but which appears to present some notable differences; I have not yet been able to compare it with the unique and type specimen of $N$. Rissoanus, from Nice, now in the Turin Zoological Museum, and of which no scientific description was ever published. My specimen was also caught near Nice in August of last year. $N$. Rissoanus should be generically distinguished from the other known species from which it differs in many essential characiers. Lütken and I believe Günther have expressed the same opinion. I should, therefore, propose the name Paradoxichthys, and should that term be pre-occupied, the equivalent Teratichthys. Should the specimen I have turn out specifically distinat from $P$. Rissoanus, I should like to call it Parad $x$ xichthys Garibaldianus, dedicating it to a great Nizzardo and fellow-countryman of Risso.
Flor nce, March 23
Henry H. Giglioli

\section{PROF. BARFF'S NEW ANTISEPTIC}

$\mathrm{I} \mathrm{N}$ a communication to the Society of Arts, March 29, 1882, a long and interesting paper was read by Prof. Barff on a "New Antiseptic Compound" applicable to the preservation of articies of food.

The compound in question is an ether of boric acid and glycerine of the composition $\mathrm{BO}_{3} \mathrm{C}_{3} \mathrm{H}_{5}$ (the chemical description in the paper is inaccurate), first obtained by Schiff and Becchi (Compt. Rendus, 62, p. 397, and J.pr. chem., 98, 184!. Experiments made with this substance on various articles of food, both solid and liquid, seem to have yielded very satisfactory results, as far as the preserving action is concerned; but neither in the paper nor in the interesting discussion which followed its reading does it appear that the preserving action is due specially to the compound in question, or to one of its constituents.

That boric acid acts as a preventive of decomposition in organised bodies when present in considerable quantity there is no doubt, but very little is known of its action in 